\title{
The Art of Steel Structures
}

\section{Xing $\mathrm{Ma}^{*}$}

School of Natural and Built Environments, University of South Australia, Mawson Lakes, SA 5095, Australia

Iron has been used as construction material in human society for long time. The first iron-chain suspended bridge, $106 \mathrm{~m}$ span Jihong Bridge, was built in Southwest China in 1400s. In Europe, the first cast iron bridge appeared in 1700s in Telford, England. Cast iron was later replaced by more reliable wrought iron for construction of most railway bridges in early 1800 s. It was not until late 1800 s / early 1900 s that steel structural systems appeared and took over iron in modern construction industry. Based on the manufacturing procedure, steel structures can be separated into two main categories: hot-rolled steel and cold-formed steel. Accordingly, there are two independent design and constructional systems.

After more than one century's development, steel has become the second widely used structural material after concrete in civil engineering industry. Because of its high strength-weight ratio, superior ductility and complete recyclability, steel has potential advantages in high-rise buildings, long-span structures, structures subject to heavy loadings or seismic loadings, and light-weighted structures.

Hook's law (1660), Euler's buckling formula (1757) and Timoshenko's plate buckling theory (1969) formed the fundament of steel design theory. Further studies were mainly focused on structural performance improvement and the determination of structural responses due to static loads, dynamic loads/actions and fire. Researches were carried out through experimental study, analytical/ numerical simulation, and field measurement in the following areas:
(1) Manufacture technology and material property improvement;

(2) Component behaviour including element (plate), section and member performance;

(3) Connection/joint behaviour;

(4) Structural behaviour, risk analysis and optimum design;

(5) Steel behaviour in composite structures;

(6) Corrosion protection;

(7) Construction technology and project management.

With the arising of new materials, new technologies and new structural systems, there is a great need of investigation on new research topics such as

(1) Development and application of high-strength steel;

(2) Huge steel structural systems;

(3) Multi-structural or structural-environment interactive study;

(4) BIM (Building Information Modelling) in steel structures.

The annual world crude steel production has reached 1.6 trillion metric tonnes recently. Structural engineers are facing more chances and more challenges in steel engineering practise.
*Corresponding author: Xing Ma, School of Natural and Built Environments, University of South Australia, Mawson Lakes, SA 5095, Australia, E-mail: Xing.Ma@unisa.edu.au

Received September 02, 2015; Accepted September 03, 2015; Published September 10, 2015

Citation: Ma X (2015) The Art of Steel Structures. J Steel Struct Constr 1: e102. doi:10.4172/2472-0437.1000e102

Copyright: (c) $2015 \mathrm{MaX}$. This is an open-access article distributed under the terms of the Creative Commons Attribution License, which permits unrestricted use, distribution, and reproduction in any medium, provided the original author and source are credited. 